\title{
Evaluation of water quality in public drinking fountains
}

\author{
M. H. Rebelo, A. S. Cardoso \& S. A. Feliciano \\ Environmental Health Department, \\ Instituto Nacional de Saúde Dr. Ricardo Jorge, Portugal
}

\begin{abstract}
This work is a prospective study in the Sintra Municipality. The objective was to identify and to characterize health risk for the population due to the consumption of drinking water from public fountains. To achieve this objective, water quality was evaluated and the physiochemical and bacteriological stability was monitored throughout the hydrologic year. For this study 42 public drinking fountains were selected whose water was subjected to bacteriological and physiochemical analysis from February 2006 to April 2007. The analytical protocol and the assessment of the obtained results were based on the quality requirements for drinking water, defined in Portuguese Law 243/2001 of September 5 . The bacteriological analyses were made with monthly periodicity; the physiochemical characterization analyses were made every two months; the metals were analyzed every six months and the pesticides and polycyclic aromatic hydrocarbons were analyzed once during the period of the study. The obtained results emphasize the poor quality of the water, observed in almost all the springs studied due, particularly, to bacteriological alterations. For this reason, water consumption from the studied public fountains in the Sintra Municipality seems to present a high risk for the population's health, due to the potential contamination with pathogenic microorganisms. The risk of chronic intoxication, though of smaller importance due to the irregular consumption of these waters, should not be excluded since some springs presented a high content of nitrate, nickel, lead and manganese.

The obtained results provide the necessary information for health risk management by the Health Authorities, through implementation of corrective measures for protection of water quality, and/or alerting the population to the health risk due to the consumption of unsafe water.

Keyword: water quality, drinking water fountains, risk assessment, water spring quality, contamination of spring waters.
\end{abstract}




\section{Introduction}

For several centuries, the fountains, with natural water, constituted the main origins of water for the population. These waters are still used by a number of people because there remains the idea that natural water is of better quality than tap water and that some natural water possesses therapeutic properties. A study developed by a Portuguese Regulator Institute (Instituto Regulador de Águas e Resíduos), based on 1000 phone interviews (sample error $=3.1 \%$ for $95 \%$ probability), from February 22 to March 3 (2007), which included people older than 18 years, revealed that $16.3 \%$ of people drink water from fountains or their own water supply and that the water quality of $71.5 \%$ for the Lisbon area fountains (where Sintra is included) is not monitored or is just monitored occasionally [1].

The Portuguese Law 306/2007 of August 27 [2] is the first normative to establish competences for the fountains' water quality. However, competences regarding the management and preservation of these resources are still lacking, which constitutes a concern for the Health Authorities.

This study's general purpose is to identify and characterize the health risks due to the consumption of water from fountains, supplied with natural water, located in the Sintra Municipality. With this in mind, the water quality evaluation was done in agreement with the defined requirements in the Law 243/2001 [3] and the physiochemical and bacteriological stability were studied for 12 months.

The obtained results supply the necessary information for the appropriate health risk management by the Health Authorities, through the implementation of correctives measures for improvement/protection of the water quality and/or risk communication [4].

\section{Technical and methodological description}

\subsection{Sample dimension and characterization}

For the characterization of the fountains inventoried by the Health Services of the Sintra Municipality (about 60 fountains), a preliminary evaluation for "knowledge of the field situation" was carried out regarding the location, accessibility and flow. This evaluation allowed the selection of 42 fountains considered more likely to be used by the local population or by pedestrians in recreation activities.

The samples were collected by the Environmental Health Technicians of the Health Centres of Sintra between February 2006 and April 2007. For setting up the periodicity of samples' collection, the health risks associated with the water consumption were considered. The bacteriological contamination is usually associated with acute effects; the risk is occasional, which forces a large surveillance of the water quality. For this reason, the collection of samples for bacteriological analysis was made with monthly periodicity. The chemical contamination is usually associated with medium or long period risks due to the 
regular and continuous consumption during months or years of chemically contaminated water. For this reason, the collection of samples for physiochemical analysis was made every two months. [5]. The collection of samples for determination of chemical contaminants was made with variable periodicity as follows:

Determination of metals: half-yearly samples collected in April and October 2006; Determination of polycyclic aromatic hydrocarbons: annual samples collected in October or November 2006; Determination of pesticides and other chlorinated compounds: annual samples collected in March or April 2007.

\subsection{Experimental essays}

The elaboration of the analytical protocol was based on the constant indications of the Law 243/2001:

- Bacteriological analysis: determination of total colony count at $22^{\circ} \mathrm{C}$ and $37^{\circ} \mathrm{C}$, total coliform bacteria, Escherichia coli, enterococci and Clostridium perfringens.

- Physiochemical characterization: odour, colour, turbidity, $\mathrm{pH}$, electric conductivity, total hardness, chloride, sulphate, sodium, potassium, iron and fluoride. In this summary analysis, nitrate, ammonia, nitrite and permanganate index, which constitute environmental contamination indicators, were included.

- Determination of undesirable chemical parameters or with proven health risk: antimony, arsenic, cadmium, lead, copper, chromium, manganese, mercury, nickel, tetrachloroethene, trichloroethene, pesticides and polycyclic aromatic hydrocarbons (PAH) [5,6]. The quantified pesticides were the following: lindane, aldrin, heptachlor, heptachlor exo-epoxide, heptachlor endo-epoxide, $\alpha$ endossulfan, $\beta$-endossulfan and dieldrin. The quantified PAH were the following: benzo(b)fluoranthene, benzo(k)fluoranthene, benzo(ghi)perylene, indeno(1,2,3-cd)pyrene and benzo(a)pyrene.

\subsection{Water quality evaluation}

The total data was observed and "higher values than" and "smaller values than" were eliminated. A descriptive analysis was applied to the remaining results, for the determination of the range of the results, the average, the standard deviation, the variation coefficient and the median [7]. For each spring, the conformity evaluation of the obtained analytical results, within the analytical period, with the defined quality requirements in the Law 243/2001, was carried out.

The springs were classified as high, medium or low risk, or without risk, in agreement with the following criteria:

High Risk: Presence of E. coli, enterococci and/or Clostridium perfringens

Medium Risk: Absence of E. coli, enterococci and/or Clostridium perfringens and presence of chemical pollutants with proven health risk (HAP, pesticides, composed chlorinated, metals, nitrates) in higher concentrations than the Parametric Value (PV). 
Low Risk: Absence of E. coli, enterococci and/or Clostridium perfringens and chemical compositions that are a proven health risk in higher concentrations than the PV.

Absence of Risk: Absence of bacteriological and physiochemical alterations based on the defined quality requirements in DL 243/2001 and observance of physiochemical and bacteriological stability of the water during the analytical period.

For the definition of the health risk, the only bacteriological results considered were the ones obtained for E. coli, enterococci and Clostridium perfringens since, from the point of view of the health risk, these are the most important parameters [5].

\subsection{Physicochemical and bacteriological stability of the waters}

The parameters selected for this study were the following: E. coli, electric conductivity, turbidity, total hardness, nitrates and permanganate index. These parameters are intended to be representative of the physicochemical characteristics of the water in the origin and indicatives of its vulnerability to faecal and agricultural contaminations and/or to the direct contamination of the mines or water conducts by residues of superficial circulation.

The physiochemical and bacteriological stability of the water was evaluated in agreement with the following criterion: it was considered that the water quality was stable if the obtained variation coefficient, in the totality of the analyses for each analytical parameter, were inferior to the triple of the precision of the respective analytical method (Table 1). This criterion intends to eliminate the result variation due to the analytical method.

Table 1: $\quad$ Precision of the analytical methods for the selected parameters and physiochemical and bacteriological stability criterion.

\begin{tabular}{ccc}
\hline \hline Parameters & $\begin{array}{c}\text { Precision of the } \\
\text { method }\end{array}$ & Stability criterion \\
\hline E.coli & $41 \%$ & $123 \%$ \\
Electric Conductivity at $20^{\circ} \mathrm{C}$ & $1.2 \%$ & $3.6 \%$ \\
Turbidity & $3.4 \%$ & $10 \%$ \\
Total hardness & $1.8 \%$ & $5.4 \%$ \\
Nitrates & $2.4 \%$ & $7.2 \%$ \\
Permanganate index & $3.8 \%$ & $11 \%$ \\
\hline \hline
\end{tabular}

\subsection{Caudal variation during the analytical period}

In this study it was considered that the caudal was constant if the variation coefficient was inferior to $25 \%$. Because the flow was measured in a rudimentary way (time necessary to fill a container with a litre of capacity), this variation intends to minimize the error due this measurement. 


\section{Results}

\subsection{Evaluation of water quality}

Tables 2 and 3 summarize the results of the evaluation of the water quality. Analysing the totality of the analyses, it is observed that a great number of samples do not meet the defined quality requirements in the Law 243/2001. This number is particularly high in bacteriological parameters. The total coliforms appear altered in $87 \%$ of the analyses, the E. coli in $59 \%$, the enterococci in $56 \%$ and the Clostridium perfringens in $14 \%$. In the physiochemical analysis, nitrates and turbidity appear altered in a larger number of samples: $37 \%$ of the analyzed samples possess nitrate concentration higher than $50 \mathrm{mg} / \mathrm{L}$ and $11 \%$ possess a turbidity value higher than 4 NTU. The alterations in the colour, permanganate index, iron and ammonia are lower. The remaining physiochemical parameters do not present alterations comparing to the PV. In the metals analysis the following alterations are observed: a sample with manganese concentration higher than the PV, seven samples with nickel concentration higher than the PV and a single sample with lead concentration higher than the PV. The PAH concentration, pesticides and other chlorinated compounds are in agreement with Law 243/2001.

Table 2: $\quad$ Number of analyses, for analytical parameters, that do not meet the requirements of bacteriological quality defined in Law 243/2001.

\begin{tabular}{|c|c|c|c|c|c|c|c|c|c|c|}
\hline \multirow[b]{2}{*}{ Parameters } & \multicolumn{2}{|c|}{$\begin{array}{c}\text { Sintra } \\
(n=240)\end{array}$} & \multicolumn{2}{|c|}{$\begin{array}{c}\text { Pêro } \\
\text { Pinheiro } \\
(n=154)\end{array}$} & \multicolumn{2}{|c|}{$\begin{array}{l}\text { Queluz } \\
(\mathrm{n}=84)\end{array}$} & \multicolumn{2}{|c|}{$\begin{array}{c}\text { Algueirão - } \\
\text { Mem } \\
\text { Martins } \\
(\mathrm{n}=12)\end{array}$} & \multicolumn{2}{|c|}{$\begin{array}{l}\text { TOTAL } \\
(\mathrm{n}=490)\end{array}$} \\
\hline & 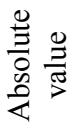 & $\%$ & 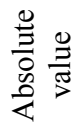 & $\%$ & 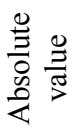 & $\%$ & 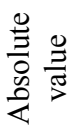 & $\%$ & 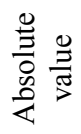 & $\%$ \\
\hline $\begin{array}{c}\text { Total } \\
\text { coliform }\end{array}$ & 205 & 85 & 138 & 90 & 73 & 87 & 12 & 100 & 428 & 87 \\
\hline E. coli & 145 & 60 & 86 & 56 & 48 & 57 & 12 & 100 & 291 & 59 \\
\hline Enterococci & 133 & 55 & 78 & 51 & 49 & 58 & 12 & 100 & 272 & 56 \\
\hline $\begin{array}{c}C . \\
\text { perfringens }\end{array}$ & 26 & 11 & 25 & 16 & 12 & 14 & 5 & 42 & 68 & 14 \\
\hline
\end{tabular}

$\mathrm{n}=$ total number of analyses for analytical parameter.

Table 4 shows the summary of the water quality evaluation for the analyzed springs, in agreement with the defined criterion in section 2.3. It was verified that, of the 42 studied springs, only seven were classified as "Low Risk", four as "Medium Risk" and the remaining as "High Risk". None was classified as "Absence of Risk." 
Table 3: Number of analyses, for analytical parameters, that do not meet the requirements of physiochemical quality defined in Law 243/2001.

\begin{tabular}{|c|c|c|c|c|c|c|c|c|c|c|}
\hline \multirow[b]{2}{*}{ Parâmetros } & \multicolumn{2}{|c|}{ Sintra $(n=120)$} & \multicolumn{2}{|c|}{$\begin{array}{c}\text { Pêro } \\
\text { Pinheiro } \\
(\mathrm{n}=78)\end{array}$} & \multicolumn{2}{|c|}{$\begin{array}{l}\text { Queluz } \\
(n=42)\end{array}$} & \multicolumn{2}{|c|}{$\begin{array}{c}\text { Algueirão } \\
\text { - Mem } \\
\text { Martins } \\
(\mathrm{n}=6)\end{array}$} & \multicolumn{2}{|c|}{$\begin{array}{l}\text { TOTAL } \\
(\mathrm{n}=246)\end{array}$} \\
\hline & 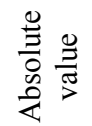 & $\%$ & $\begin{array}{l}0 \\
\frac{0}{3} \\
0 \\
0 \\
0 \\
0\end{array}$ & $\%$ & 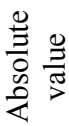 & $\%$ & 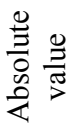 & $\%$ & 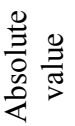 & $\%$ \\
\hline Color & 3 & 2,5 & 1 & 1,3 & 0 & 0 & 0 & 0 & 4 & 1,6 \\
\hline Turbidity & 19 & 16 & 7 & 9,0 & 0 & 0 & 0 & 0 & 26 & 11 \\
\hline Nitrates & 42 & 35 & 38 & 49 & 11 & 26 & 0 & 0 & 91 & 37 \\
\hline Iron & 7 & 5.8 & 6 & 7.7 & 0 & 0 & 0 & 0 & 13 & 5.3 \\
\hline $\begin{array}{c}\text { Permanganate } \\
\text { index }\end{array}$ & 5 & 4.2 & 2 & 2,6 & 0 & 0 & 0 & 0 & 7 & 2.8 \\
\hline Ammonia & 0 & 0 & 7 & 9.0 & 0 & 0 & 0 & 0 & 7 & 2.8 \\
\hline
\end{tabular}

$\mathrm{n}=$ total number of analyses for analytical parameter.

Table 4: $\quad$ Summary of water quality (criterion defined in section 2.3).

\begin{tabular}{|c|c|}
\hline Risk Assessment & $\begin{array}{c}\text { Number of springs } \\
(\mathbf{n}=\mathbf{4 2})\end{array}$ \\
\hline HIGH RISK & 38 \\
\hline MEDIUM RISK & 2 \\
\hline LOW RISK & 2 \\
\hline ABSENCE OF RISK & 0 \\
\hline
\end{tabular}

$\mathrm{n}=$ total number of springs.

\subsection{Evaluation of the physiochemical and bacteriological water stability}

Table 5 presents the summary evaluation of the physiochemical and bacteriological water stability, throughout the analytical period, for each one of the selected parameters. According to the defined criterion in section 2.3, it is observed that the turbidity and the permanganate index present variability of results in all the springs studied. For the remaining parameters, although the variability is inferior to $100 \%$, it is still quite high.

\subsection{Study of the caudal variation along the analytical period}

The coefficient of variation of the caudal is between 18 and $151 \%$. Only three springs present a value equal or inferior to $25 \%$, which means that, in agreement with the defined criterion, only three springs possessed a stable caudal during the analytical period. 
Table 5: Number of springs that present variability of results (criterion defined in section 2.3).

\begin{tabular}{|c|c|c|c|c|c|c|c|c|c|c|}
\hline & \multicolumn{2}{|c|}{$\begin{array}{l}\text { Sintra } \\
(\mathrm{n}=20)\end{array}$} & \multicolumn{2}{|c|}{$\begin{array}{c}\text { Pêro } \\
\text { Pinheiro } \\
(n=13)\end{array}$} & \multicolumn{2}{|c|}{$\begin{array}{l}\text { Queluz } \\
(\mathrm{n}=7)\end{array}$} & \multicolumn{2}{|c|}{$\begin{array}{l}\text { Algueirão } \\
\text { - Mem } \\
\text { Martins } \\
(\mathrm{n}=2)\end{array}$} & \multicolumn{2}{|c|}{$\begin{array}{l}\text { TOTAL } \\
(\mathrm{n}=42)\end{array}$} \\
\hline Parameters & 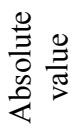 & $\%$ & 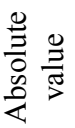 & $\%$ & 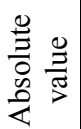 & $\%$ & 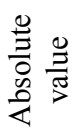 & $\%$ & 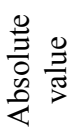 & $\%$ \\
\hline E. coli & 11 & 55 & 8 & 62 & 3 & 43 & 2 & 100 & 24 & 57 \\
\hline $\begin{array}{c}\text { Electric } \\
\text { Conductivity at } \\
20^{\circ} \mathrm{C} \\
\end{array}$ & 15 & 75 & 10 & 77 & 4 & 57 & 1 & 0 & 30 & 71 \\
\hline Turbidity & 20 & 100 & 13 & 100 & 7 & 100 & 2 & 100 & 42 & $\begin{array}{c}10 \\
0\end{array}$ \\
\hline Total Hardness & 16 & 80 & 9 & 69 & 4 & 57 & 2 & 100 & 31 & 74 \\
\hline Nitrates & 18 & 90 & 13 & 100 & 7 & 100 & 2 & 100 & 40 & 95 \\
\hline $\begin{array}{c}\text { Permanganate } \\
\text { index }\end{array}$ & 20 & 100 & 13 & 100 & 7 & 100 & 2 & 100 & 42 & $\begin{array}{c}10 \\
0\end{array}$ \\
\hline
\end{tabular}

n. = number of springs studied.

\section{Conclusion}

Of the 42 springs studied, only two were classified as "Low Risk" because they presented an absence of $E$. coli, enterococci and $C$. perfringens and two were classified as "Medium Risk" because they present alterations in parameters with a proven health risk. The remaining springs were classified as "High Risk."

In the face of the obtained results, the main conclusion is related to the poor water quality observed in almost all the studied springs due, mainly, to the potential contamination with pathogenic microorganisms [5,8]. A general conclusion is that the consumption of water from public fountains in the Sintra Municipality presents a high health risk. The risk of chronic intoxication, although of lesser importance, due to the irregular consumption of these waters, should not be excluded since a high concentration of nitrates was observed in more than half of the analyzed samples. In different springs high nickel, manganese and lead concentrations were also observed.

The following complementary findings seem to also be of major relevance in the definition of recommendations to supply to the Health Authorities and in the implementation of eventual corrective measures:

1) Most of the fountains seem to have their origin in aquifers of small depth and are very vulnerable to pollution. This explains the strong bacteriological contamination observed in most of the waters, the high nitrate concentration in $37 \%$ of the analyzed samples, the great variability of the results obtained during the analytical period and the caudal instability [9].

2) The deficient maintenance conditions of mines and conducts seem to contribute to the poor water quality. This idea is supported mainly by the high 
variability of the obtained results in the parameters E. coli, turbidity and permanganate index (range of the variation coefficients: E. coli $0-346 \%$, turbidity $32-194 \%$ and permanganate index $11-104 \%$ ).

The major source of contamination identified in this study is connected with domestic and agricultural activity. The microorganisms of faecal origin can reach spring waters through the unloading of the residual urbane waters in the water flow or in the soil, due to accidents related to breaks in cesspits or drainage systems or due to infiltration from sanitary landfills or agricultural areas. Agricultural activity is also responsible for the contamination of spring waters with nitrates due to the application of fertilizers in the soils.

\section{Recommendations}

The recovery of contaminated aquifers is a very slow process that implicates the elimination of the source of contamination that, in practice, is revealed to be impossible in most of the cases. The contamination due to deficient maintenance conditions of mines and conducts can be controlled through appropriate interventions of cleaning and rehabilitation of structures. In this context, the main recommendations of this work are the following:

1) Communication, by the Health Authorities, of the risks that the population incur in consuming inappropriate water.

2) Verification of the cleaning and maintenance conditions in the final structures of the watercourse, in the underground of each spring. The ones that are found to be in poor condition should be submitted to a rehabilitation process.

3) After the necessary interventions for the rehabilitation of the springs, the water quality should be evaluated. The springs whose water continues to be classified as "High Risk" should be closed.

4) Springs that do not present alterations in the final structure of the watercourse underground, and are still classified as "High Risk", should be closed once it is confirmed that the poor water quality is due to aquifer contamination.

5) Springs maintained accessible to the population should be monitored through appropriate programs of sanitary surveillance.

\section{Acknowledgement}

This study was awarded by the Portuguese Commission for the Investigation in Health Care (Comissão de Fomento da Investigação em Cuidados de Saúde Ministério da Saúde)

\section{References}

[1] Simas L. \& Guerreiro S., A Qualidade da Água para Consumo Humano em Portugal - Que Água Bebem os Portugueses? Personal communication, May 2007, Instituto Regulador de Águas e Resíduos, Lisboa, Portugal. 
[2] Law 306/2007 - Diário da República I Series, 164, August 27.

[3] Law 243/2001 - Diário da República I Series, 206, September 5.

[4] Corey, O.G., Vigilância em epidemiologia ambiental. WHO, Série Vigilância 1, Metepee, México, 1988.

[5] Guidelines for drinking water quality, Recommendations 1; World Health Organization, Geneva, 2004.

[6] Gray, N.F., Problems with the resource (Chapter 4). Drinking Water Quality, Problems and Solutions, ed. John Wiley \& Sons, pp 113-175, 1996.

[7] Miller, J.C. \& Miller J.N., Statistics for Analytical Chemistry, Third edition, Ellis Horwood PTR Prentice Hall, 1993

[8] Unite States Environmental Protection Agency (USEPA). Ground water \& drinking water, List of drinking water contaminants Web Site, Washington DC, www.epa.gov/ogwdw/mcl.html

[9] Oliveira, M., Novo M.E., Moinante M.J. \& Ferreira, J.P.L., Plano de Bacia Hidrográfica do Rio Tejo, $1^{\mathrm{a}}$ Fase, Análise e Diagnóstico da Situação Actual, Anexo Temático 4 - Recursos Hídricos Subterrâneos, Tomo A Caracterização Hidrogeológica; Laboratório Nacional de Engenharia Civil, Departamento de Hidráulica, Grupo de Investigação de Águas Subterrâneas, Lisboa, 2000. 